\title{
Penerapan Model Problem Posing Bersetting Cooperatif Tipe Think Pair Shaere Pada Topik Asam Basa Untuk Meningkatkan Penguasaan Konsep Mahasiswa
}

\author{
Rahmat Rasmawan \\ Program Studi Pendidikan Kimia FKIP Untan
}

\begin{abstract}
Abstrak
The low student understanding of concepts on the topic due to lack of acid base interaction with the material studied. This study aims to determine the conception of students, student influence and respond to the model after learning problems set Posing think pair share. The sample in this study is the students who attend a course basic chemistry II 2008/2009 school year in chemical education courses totaling UNTAN FKIP 23 people with a form of research design quasy experiment. Data collection techniques used is about the shape of the test and questionnaire response essays. The results showed that there are significant differences abilities before learning concepts with students after learning. The amount of influence of 7.49 with a very high category. Conceptions of students in accordance with the concept of the experts increased by $52.9 \%$. Students respond positively to the learning model of cooperative problem set type possing think pair share.
\end{abstract}

\section{Kata Kunci: Asam basa, Problem Posing, Kooperatif, Think Pair Share.}

\section{A. PENDAHULUAN}

Salah satu masalah utama dalam bidang pendidikan di Indonesia adalah rendahnya mutu guru yang diduga memiliki kontribusi signifikan terhadap rendahnya mutu pendidikan. Lembaga Pendidikan Tenaga Kependidikan (LPTK) sebagai institusi memiliki peran yang sangat vital untuk membangun sistem pembelajaran yang berkualitas. Tugas utama LPTK adalah menghasilkan tenaga kependidikan berkualitas tinggi yang akan bekerja pada berbagai satuan pendidikan. Perubahanperubahan yang terjadi dengan cepat menyebabkan kualitas pembelajaran pada waktu yang lalu dan hari ini segera menjadi kadaluarsa pada hari esok. Dengan demikian upaya peningkatan kualitas pembelajaran harus dilakukan terus menerus dan tidak ada hentinya.

Program Studi Pendidikan kimia FKIP Untan ikut bertanggung jawab dalam mendidik calon guru kimia yang memiliki kompetensi sebagai guru profesional. Salah satu usaha yang dapat dilakukan untuk mendidik calon guru professional adalah penguasaan materi. Penguasaan materi termasuk dalam kompetensi bidang substansi atau bidang studi (Depdiknas, 2001). 
Menurut Paul Suparno (2004) kompetensi bidang substansi mengharuskan guru menguasai kurikulum, menguasai materi pelajaran, memahami kebijakankebijakan pendidikan, pemahaman pada karakteristik dan isi bahan pembelajaran, menguasai konsepnya, memahami konteks ilmu tersebut dengan masyarakat dan lingkungan, memahami bagaimana dampak dan relasi ilmu tersebut dalam kehidupan masyarakat dan dengan ilmu yang lain.

Salah satu konsep dasar ilmu kimia yang penggunaannya cukup luas adalah kimia larutan khususnya asam dan basa. Konsep asam-basa banyak digunakan dalam kimia organik seperti pemanfaatan asam basa sebagai katalis reaksi organik sintesis, sifat senyawa organik. Dalam kimia analitik konsep asam basa banyak digunakan dalam analisis baik kualitatif maupun kuantitatif seperti penentuan kadar asam atau basa serta analisis yang terjadi pada $\mathrm{pH}$ tertentu. Dalam kimia anorganik, konsep asam basa sering dipakai dalam penentuan sifat suatu mineral dan sebagainya.

Namun kenyataannya, masih banyak mahasiswa program studi Pendidikan Kimia FKIP Untan yang kesulitan dalam mempelajari materi asam dan basa. Hal ini diketahui dari hasil matrikulasi mahasiswa angkatan 2007 dan 2008 pada bahasan asam basa hanya memperoleh nilai rata-rata 49,25. Dari mahasiswa yang telah mengikuti perkuliahan kimia dasar didapati informasi bahwa materi kimia larutan khususnya asam basa termasuk materi yang sulit mereka kuasai. Hal ini disebabkan karena cara penyampaian dosen yang begitu cepat, kurangnya latihan soal-soal materi asam basa, serta kurangnya interaksi dengan teman kuliah karena pembelajaran hanya berpusat pada dosen.

Hasil diskusi dengan dosen yang mengajar mata kuliah Kimia Dasar menuturkan bahwa mahasiswa banyak mengalami kendala memahami konsep asam dan basa terutama menentukan $\mathrm{pH}$ larutan buffer dan $\mathrm{pH}$ titrasi. Hal ini disebabkan dosen harus mengulang materi mol dan konsentrasi larutan. Metode yang dipakai dosen rata-rata menggunakan ceramah dan penyajian yang singkat. Hal ini dikarenakan para dosen beranggapan bahwa mahasiswa telah memperoleh materi asam basa telah diterima mereka pada waktu SMA sehingga di perkuliahan hanya mengulang atau mengingatkan kembali konsep tersebut.

Dosen sebagai pengajar sudah seharusnya mendesain pembelajaran yang dapat mendorong mahasiswa aktif secara kognitif dari pada hanya aktif prilakunya. Aktif secara kognitif merupakan unjuk kerja utama bagi mahasiswa tersebut, yaitu dengan mencoba menjelaskan dengan cara sendiri hasil interaksinya dengan materi pelajaran atau percobaan (Mayer 1999).

Model penyampaian materi yang "teacher center" mengakibatkan konstruksi pengetahuan secara bermakna tidak terjadi. Mahasiswa masih berpatokan pada jalan penyelesaian dosen, seolah-olah cara penyelesaian dosen merupakan cara yang baku. Akibatnya bila mahasiswa diberikan soal yang bervariasi, mereka mengalami kesulitan untuk menyelesaikannya. Untuk itu perlu dipikirkan rancangan pembelajaran yang memberikan kesempatan pada 
mahasiswa menjelaskan hasil interaksinya dengan materi yang disampaikan Model problem Posing tidak hanya berpusat pada pengajar (teacher centered instruction) tetapi juga memberikan kesempatan pada mahasiswa dapat menyusun atau membuat soal setelah kegiatan pembelajaran dilakukan sebagai hasil interaksinya dengan penyampaian materi yang diberikan dosen (Nakato, 2000). Model problem posing dapat mengembangkan kemampuan matematis atau menggunakan pola pikir matematis (Suryanto, 1998). Pada .perkuliahan kimia dasar, pembelajaran materi asam basa lebih menekankan pada aspek kuantitatif (perhitungan) khususnya menghitung $\mathrm{pH}$ larutan dan $\mathrm{pH}$ titrasi asam basa.

Selanjutnya dalam pembelajaran model problem posing pengajar juga perlu mensetting suasana belajar agar terjadi interaksi antar mahasiswa. Menurut Slavin (1995) interaksi antar mahasiswa perlu diterapkan karena adanya upaya antar mahasiswa untuk mencapai tujuan prestasi akademik bersama tanpa adanya persaingan individu. Suasana belajar yang dapat memunculkan interaksi anata mahasiswa adalah kooperatif. Pembelajaran kooperatif merupakan pembelajaran yang menekankan adanya kerja sama dalam kelompok dan saling menguntungkan antar siswa. Salah satu dari pembelajaran kooperatif adalah Think-Pair-Share ( TPS). Menurut Anita Lie (2004) pembelajaran Think-Pair-Share (TPS) adalah pembelajaran yang memberi siswa kesempatan untuk bekerja sendiri serta bekerja sama dengan orang lain. Jumlah satu kelompok dalam TPS hanya berjumlah 2 orang saja, sehingga para mahasiswa dalam satu kelompok lebih banyak kesempatan untuk kontribusi dalam penyelesaian masalah dan interaksi akan lebih mudah.

Belum diperoleh jaminan tentang manfaat dan efektivitas serta belum dikenal secara meluas oleh dosendosen pendidikan kimia FKIP Untan tentang pembelajaran model problem posing bersetting think pair share, maka penelitian ini dipandang perlu untuk dilakukan. Dalam hal ini akan dilihat pemahaman konsep materi asam basa pada mahasiswa program studi pendidikan kimia FKIP Untan, sehingga melalui penelitian ini dapat menjadi salah satu alternatif solusi terhadap permasalahan rendahnya pemahaman konsep asam dan basa yang masih sering dikeluhkan oleh tenaga pengajar kimia dasar. Penelitian ini juga diharapkan dapat meningkatkan kualitas sumber daya manusia (dosen dan mahasiswa).

Permasalahan yang diangkat dalam penelitian ini adalah (1)Bagaimana profil konsepsi mahasiswa sebelum dan sesudah pembelajaran dengan model problem possing bersetting think pair share ?(2)Apakah ada pengaruh pembelajaran dengan menggunakan model pembelajaran problem posing bersetting think pair share pada materi asam basa?(3)Seberapa besar pengaruh pembelajaran dengan menggunakan model pembelajaran problem posing bersetting think pair share pada materi asam basa? (4) Bagaimanakah respon siswa setelah pembelajaran dengan menggunakan model problem posing bersetting tink pair share.

Tujuan dari penelitian ini adalah untuk (1) menggambarkan konsepsi mahasiswa sebelum daan sesudah 
pembelajaran dengan model problem posing bersetting think pair share pada topic asam basa. (2) Mengetahui apakah ada pengaruh pembelajaran dengan menggunakan model pembelajaran problem posing bersetting think pair share pada topic asam basa. (3) Besarnya pengaruh pembelajaran model problem posing bersetting think pair share pada topic asam basa. (4) Menggambarkan respon mahasiswa setelah pembelajaran dengan menggunakan model problem posing bersetting think pair share pada topic asam basa.

Menurut Pittalis, dkk (2004) problem posing mempunyai arti yaitu perumusan soal sederhana atau perumusan ulang soal yang ada dengan beberapa perubahan agar lebih sederhana dan dapat dikuasai. Dari pegertian tersebut, terdapat dua aspek penting yaitu accepting dan challeging. Accepting berkaitan dengan kemampuan siswa dalam memahami situasi yang diberikan oleh guru atau situasi yang sudah ditentukan. Sedangkan challeging berkaitan dengan sampai sejauah mana siswa merasa tertantang dari situasi yang diberikan sehingga memiliki kemampuan untk membuat soal matematika, sehingga problem posing matematika dapat membantu siswa untuk mengembangkan proses nalar mereka.

Pembelajaran model Think-PairShare (TPS) merupakan model pembelajaran kooperatif dimana siswa belajar dalam diskusi kelompok yang terdiri dari dua orang secara heterogen dan bekerja sama saling ketergantungan positif dengan menulis ide-ide dari pemikiran setiap individu kemudian berbagi bersama untuk meningkatkan respon siswa pada pertanyaan/masalah. Pembelajaran model Think-PairShare (TPS) bertujuan untuk meningkatkan rasa tanggung jawab siswa terhadap pembelajaran orang lain. Siswa tidak hanya mempelajari materi yang diberikan, tetapi harus mengembangkan pola pikir dengan ide-ide baru dalam memahami materi yang diberikan sehingga dapat memotivasi siswa yang lainnya agar memiliki pola pikir yang baik pula. Menurut Muslimin Ibrahim, dkk (2000: 26), model pembelajaran Think-Pair-Share memiliki tahaptahap sebagai berikut:

1) Thinking (Berpikir)

Guru mengajukan

pertanyaan atau isu yang berhubungan dengan pelajaran, kemudian siswa diminta untuk memikirkan pertanyaan atau isu tersebut secara mandiri untuk beberapa saat.

2) Pairing (Berpasangan)

Guru meminta siswa berpasangan dengan siswa yang lain untuk mendiskusikan apa yang telah dipikirkan pada tahap pertama. Interaksi pada tahap ini diharapkan dapat berbagi jawaban jika telah diajukan suatu pertanyaan atau berbagai ide jika suatu persoalan khusus telah diidentifikasi.

3) Sharing (Berbagi)

Pada tahap akhir, guru meminta kepada pasangan untuk berbagi dengan keseluruhan kelas tentang apa yang telah mereka bicarakan.

Pembelajaran model problem posing bersetting kooperatif tipe think 
pair share adalah pembelajaran yang bertujuan untuk meningkatkan penguasaan konsep mahasiswa dalam membentuk soal sejumlah soal dari kondisi yang diberikan oleh dosen secara individu. Selanjutnya dibentuk kelompok yang terdiri dari dua orang. Masing-masing anggota kelompok akan mendiskusikan permasalahan yang diberikan dan kemudian dipresentasikan hasil diskusi mereka.

Agar terjadi persamaan persepsi maka dalam penelitian ini yang dimaksud model pembelajaran problem posing bersetting kooperatif tipe think pair share adalah di dalam pembelajaran ini mahasiswa diminta untuk membuat sejumlah soal serta kunci jawaban dari kondisi yang diberikan oleh dosen secara individu. Selanjutnya dosen membentuk kelompok yang terdiri dari dua orang mahasiswa. Pengelompokan didasari tingkat pemahaman konsep yang heterogen dan berdasarkan jenis kelamin yang sama. Kelompok diberi tugas oleh dosen untuk mengerjakan soal secara bersama-sama. Soal yang diberikan berasal dari kelompok lain. Setelah menyelesaikan soal yang diberikan, kemudian kelompok tersebut memberikan hasilnya kepada kelompok pembuat soal untuk dikoreksi.

\section{B. METODELOGI PENELITIAN Bentuk Penelitian}

Penelitian ini merupakan penelitian eksperimental dengan bentuk penelitian eksperimen semu (quasy experiment design). Bentuk penelitian ini diambil karena kegiatan mengajar belajar di kelas cenderung merupakan kegiatan yang bersifat sosial, sehingga dirasakan sangat sulit untuk melakukan kontrol secara ketat variabel-variabel yang berpengaruh pada variabel terikat. Rancangan eksperimen yang digunakan adalah the one group pretes-posttest design.

\section{Populasi dan sampel}

Populasi dalam penelitian ini adalah mahasiswa program studi pendidikan kima FKIP Untan. Sampel dipilih secara porposive. Pemilihan lokasi penelitian atas pertimbangan bahwa kasus rendahnya penguasaan konsep asam basa tersebut dijumpai pada mahasiswa program studi pendidikan kimia FKIP Untan . Pada penelitian ini akan diambil sampel secara porposive. Sampel dalam penelitian hanya terbatas pada mahasiswa program studi pendidikan kimia FKIP Untan yang mengambil mata kuliah kimia dasar II pada tahun ajaran 2008/2009.

\section{Variabel penelitian}

Variabel dalam penelitian ini terdiri atas variabel bebas, terikat dan kontrol. Variabel bebas pada penelitian ini adalah pembelajaran, dengan variasinya adalah pembelajaran materi asam basa dengan model problem posing berseting think pair share. Variabel terikat pada penelitian ini adalah penguasaan konsep asam basa. Variabel control dalam penelitian ini adalah jennies kelamin. Mahasiswa yang berjenis kelamin laki-laki dikelompokan dengan mahasiswa laki-laki, dan yang perempuan dengan perempuan. Hal ini dilakukan agar masing-masing kelompok diskusi lebih mudah berlangsung.

\section{Alat pengumpul data}

Alat pengumpul data berupa tes tentang penguasaan konsep siswa 
yang diajar dengan menggunakan model problem posing bersetting think pair share. Tes ini dinyatakan dalam bentuk skor, yang terdiri dari tes awal dan tes akhir untuk mengukur perubahan hasil belajar (penguasaan konsep) setelah subyek penelitian diberi perlakuan. Tes yang digunakan bersifat paralel, dan dikembangkan dengan berpedoman pada kompetensi yang telah ditetapkan.. Validitas tes ditentukan menurut validitas isi.

Reliabilitas tes ditentukan dengan mengujicobakan perangkat tes tersebut, dan secara keseluruhan dilakukan dengan menggunakan rumus alpha, dengan alasan rumus ini dapat digunakan untuk menghitung koefisien reliabilitas tes yang skornya lebih umum, tidak hanya skor 0 dan 1 (Sutrisno, 1994) . Uji reliabilitas sebesar 0,782 dengan kategori tinggi.

Alat pengumpul data tambahan berupa soal-soal yang dibuat mahasiswa pada saat pembelajaran model problem posing bersetting think pair share. Alat pengumpul data tambahan yang diamati meliputi indikator soal yang dibuat, kaitan antar konsep, aspek kemampuan kognitif serta kebenaran kunci jawaban yang dibuat subjek penelitian pada saat pembelajaran berlangsung.

\section{Prosedur pelaksanaan penelitian}

Mengacu kepada bentuk penelitiannya, kegiatan penelitian dilaksanakan dengan mengikuti tahapan dan prosedur penelitian sebagai berikut:

a. Kelompok mahasiswa yang menjadi sampel penelitian terlebih dahulu diberikan tes awal. b. Peneliti mendiskusikan terlebih dahulu pokok-pokok pelaksanaan pembelajaran menggunakan model problem posing bersetting think pair share pada mahasiswa dalam kegiatan pembelajar materi asam basa.

c. Pada saat yang telah ditentukan diberikan perlakuan model problem posing bersetting think pair share pada sampel penelitian.

d. Mahasiswa diberi tes penguasaan konsep (posttest) setelah pembelajaran selesai.

e. Perubahan skor antara tes awal dan tes akhir dianalisis dengan uji perbandingan yang sesuai.

f. Penarikan kesimpulan dari hasil analisis pada tahap-tahap sebelumnya.

g.

\section{Rencana analisis data}

Data dianalisis dengan menggunakan program SPSS. Data posttest dan pretes diuji normalitasnya. Uji normalitas menggunakan uji liliefors. Jika ke dua data berdistribusi normal maka dilakukan uji t ( paired sampel test). Apabila kedua data atau salah satu data tidak berdistribusi normal maka dilakukan uji non parametric yaitu dengan uji wilkocson.

\section{HASIL DAN PEMBAHASAN}

Konsepsi awal mahasiswa yaitu sebelum pembelajaran dengan model problem posing bersetting kooperatif tipe tink pair share diungkap melalui analisis jawaban hasil pretes. Secara umum konsepsi siswa berbeda dengan konsep para ahli. Sebagian besar konsepsi mahasiswa yang keliru adalah menentukan $\mathrm{pH}$ campuran dari 
asam dan basa. Konsepsi akhir mahasiswa yaitu konsepsi setelah pembelajaran model problem posing bersetting think pair share diungkap melalui analisis hasil postes. Secara umum konsepsi mahasiswa telah sesuai dengan para ahli. Untuk lebih terinci dapat dilihat pada tabel 1 .

Dari tabel 1 diketahui adanya peningkatan kemampuan pemahaman konsep mahasiswa pada topik asam basa. Konsepsi awal mahasiswa 38,1 $\%$ meningkat menjadi $91 \%$. Peningkatan konsep mahasiswa terutama terjadi pada perhitungan $\mathrm{pH}$ campuran asam dan basa.

Kemampuan konsep awal mahasiswa yang berbeda dari para ahli disebabkan karena mereka pada waktu SMA hanya menghafal rumus yang diberikan guru. Untuk menentukan $\mathrm{pH}$ asam kuat dan basa kuat mereka tidak mengalami kesulitan. Tetapi untuk menentukan $\mathrm{pH}$ campuran asam basa mereka mengalami kesulitan. Kesulitan mereka dikarenakan tidak mengetahui rumus yang akan digunakan dalam menyelesaikan soal. Ketidaktahuan mereka dalam menggunakan rumus dikarenakan guru mereka pada waktu SMA jarang memberikansoal-soal latihan tentang menentukan $\mathrm{pH}$ campuran asam basa. Akibatnya mereka tidak terlatih untuk mengerjakan soal tersebut. Seharusnya dalam pengerjaannya mahasiswa harus memahami konsep perhitungan stoikiometri yaitu banyaknya mol yang bereaksi dan sisa reaksi. Belajar dengan cara menghafal hanya mampu menyelesaikan soalsoal sederhana, tetapi dalam menyelesaikan soal-soal yang memerlukan penalaran maka mengalami kesulitan.

\section{Tabel 1. Konsepsi Awal Dan Akhir Mahasiswa Pada Pokok Bahasan Asam} Basa

\begin{tabular}{|c|c|c|c|c|c|}
\hline \multirow[t]{2}{*}{ No } & \multirow[t]{2}{*}{ Konsepsi } & \multicolumn{2}{|c|}{$\begin{array}{c}\text { Jumlah mahasiswa } \\
\text { yang benar }\end{array}$} & \multicolumn{2}{|c|}{ Persentase } \\
\hline & & Awal & Akhir & Awal & Akhir \\
\hline 1 & Menghitung $\mathrm{pH}$ asam kuat & 23 & 23 & $100 \%$ & $100 \%$ \\
\hline 2 & Menghitung $\mathrm{pH}$ asam lemah & 19 & 23 & $82,6 \%$ & $100 \%$ \\
\hline 3 & Menghitung $\mathrm{pH}$ basa kuat & 23 & 23 & $100 \%$ & $100 \%$ \\
\hline 4 & Menghitung $\mathrm{pH}$ basa lemah & 19 & 23 & $21,7 \%$ & $100 \%$ \\
\hline 5 & $\begin{array}{l}\text { Menghitung } \mathrm{pH} \text { campuran asam kuat dengan } \\
\text { basa kuat } \\
\text { a. Konsentrasi asam kuat }>\text { basa kuat } \\
\text { b. Konsentrasi asam kuat }=\text { basa kuat } \\
\text { c. Konsentrasi asam kuat }<\text { basa kuat }\end{array}$ & $\begin{array}{c}5 \\
10 \\
4 \\
\end{array}$ & $\begin{array}{l}21 \\
23 \\
20 \\
\end{array}$ & $\begin{array}{l}21,7 \% \\
43,5 \% \\
17,4 \%\end{array}$ & $\begin{array}{c}91,4 \% \\
100 \% \\
87 \%\end{array}$ \\
\hline 6 & $\begin{array}{l}\text { Menghitung pH campuran asam kuat dengan } \\
\text { basa lemah } \\
\text { a. Konsentrasi asam kuat }>\text { basa lemah } \\
\text { b. Konsentrasi asam kuat }=\text { basa lemah } \\
\text { c. Konsentrasi asam kuat }<\text { basa lemah }\end{array}$ & $\begin{array}{l}3 \\
2 \\
0\end{array}$ & $\begin{array}{l}18 \\
21 \\
18 \\
\end{array}$ & $\begin{array}{c}13 \% \\
8,7 \% \\
0 \%\end{array}$ & $\begin{array}{l}78,3 \% \\
91,4 \% \\
78,3 \%\end{array}$ \\
\hline 7 & $\begin{array}{l}\text { Menghitung pH campuran asam lemah dengan } \\
\text { basa kuat } \\
\text { a. Konsentrasi asam lemah }>\text { basa kuat } \\
\text { b. Konsentrasi asam lemah = basa kuat } \\
\text { c. Konsentrasi asam lemah }<\text { basa kuat }\end{array}$ & $\begin{array}{l}0 \\
1 \\
1 \\
\end{array}$ & $\begin{array}{l}21 \\
19 \\
19 \\
\end{array}$ & $\begin{array}{c}0 \% \\
4,3 \% \\
4,3 \%\end{array}$ & $\begin{array}{l}91,4 \% \\
82,6 \% \\
82,6 \%\end{array}$ \\
\hline & Rata - Rata & & & $38,1 \%$ & $91 \%$ \\
\hline
\end{tabular}


Kemampuan akhir mahasiswa setelah pembelajaran model problem posing bersetting think pair share pada materi asam basa mengalami peningkatan. Sekitar 91\% mahasiswa telah memiliki konsepsi seperti konsepsi para ahli. Sebagian besar kesalahan mereka muncul dari perhitungan matematis. Dalam perhitungan $\mathrm{pH}$, kesalahan dalam perhitungan menyebabkan kesalahan pada kesimpulan. Kesimpulan pada perhitungan $\mathrm{pH}$ asam, basa dan campuran asam basa sangat menentukan karena telah menyangkut aspek kuantitatif. Kesalahan perhitungan yang sering dijumpai adalah penentuan mol zat hasil reaksi pada penentuan $\mathrm{pH}$ campuran asam basa. Selain itu kesalahan yang dijumpai adalah penentuan mol zat yang bereaksi. Kesalahan terutama pada perbandingan mol zat yang bereaksi. Kesalahan lain adalah kesalahan dalam menuliskan koefisien persamaan reaksi asam dan basa.

Dari kemampuan mahasiswa membuat soal belum tampak adanya variasi soal. Soal yang dibuat seperti contoh yang diberikan dosen, hanya terjadi perubahan konsentrasi dan jenis asam basanya. Hal ini disebabkan karena mahasiswa belum mengembangkan kemampuan berpikir kreatifnya dalam merumuskan soal. Selain itu, mereka terbiasa menerima materi yang disampaikan guru. Mahasiswa hanya menunggu materi tanpa ada usaha untuk membangun pengetahuan mereka sendiri. Soal yang dibuat mahasiswa seputar penentuan $\mathrm{pH}$ dari asam kuat, basa kuat, asam lemah dan basa lemah. Untuk menentukan $\mathrm{pH}$ campuran asam dan basa terdapat berbagai variasi yaitu menentukan $\mathrm{pH}$ campuran asam kuat basa kuat, asam kuat basa lemah, asam lemah basa kuat dan asam lemah basa lemah. Kunci jawaban dari soal yang dibuat mahasiswa telah sesuai dengan konsep para ahli. Perumusan kunci jawaban seperti langkah penyeleaian yang dibuat dosen. Mereka beranggapan bahwa jalan penyelesaian dosen merupakan cara baku harus di ikuti.

Untuk melihat pengaruh model pembelajaran problem posing bersetting tink pair share maka dilakukan uji statistik dengan menggunakan program SPSS. Data dari pretes diketahui rata-rata skor sebesar 17,78 dengan standar deviasi sebesar 5,410. Hasil postes menunjukan rata-rata skor sebesar 58,30 dengan standar deviasi sebesar 9,073. Uji normalitas data menunjukan bahwa skor pretes dan postes berdistribusi normal. Selanjutnya data pretes dan postes di uji statistic menggunakan uji $t$ berpasangan dua sisi dengan $\alpha=$ 0,05 . Hasil dari uji $t$ tersebut menunjukan bahwa nilai signifikansi (2-tailed) sebesar 0,001 lebih kecil dari 0,05 . Hal ini menunjukan bahwa terdapat perbedaan yang signifikan antara kemampuan awal mahasiswa sebelum pembelajaran model problem posing bersetting think pair share dengan kemampuan akir mahasiswa setelah pembelajaran model problem posing bersetting tink pair share pada materi asam basa.

Untuk mengetahui seberapa besar pengaruh penggunaan model problem posing bersetting kooperatif pada pembelajaran asam basa menggunakan efek size (ES). Hasil perhitungan ES pretes dan postes 
diperoleh sebesar 7,49 yang diklasifikasikan sangat tinggi. Hal ini menunjukan bahwa pembelajaran model problem posing bersetting kooperatif tipe tink pair share memberikan pengaruh yang cukup besar terhadap kemampuan memahami konsep mahasiswa pada materi Asam basa.

Tingginya pengaruh model pembelajaran problem posing bersetting kooperatif tipe think pair share karena mahasiswa diberi kesempatan untuk merumuskan pemahaman konsep mereka sendir berupa perumusan soal. Mahasiswa diberikan kesempatan berinteraksi dengan materi yang dipelajari. Sebelum dilakukan diskusi, mahasiswa telah memiliki pemahaman konsep sendiri Kelompok yang terdiri dari 2 mahasiswa berdasarkan jenis kelamin dan tingkat kemampuan yang berbeda memberikan kesempatan yang luas kepada mereka untuk bertukar pendapat tanpa ada rasa canggung serta adanya upaya antar mahasiswa untuk mencapai tujuan prestasi akademik bersama tanpa adanya persaingan individu. Pada akhirnya kedua pasangan dapat memahami konsep asam basa yag sesuai dengan para ahli.

Diakhir penelitian, mahasiswa diberi angket yang berisi respon mereka terhadap pembelajaran model problem posing bersetting tink pair share. Secara keseluruhan respon mahasiswa terhadap model pembelajaran ini menunjukan respon positif. Garis besar dari angket respon mahasiswa menunjukan mereka senang dengan pembelajaran model problem posing bersetting tink pair share karena mereka tertantang untuk membuat soal sesukar mungkin dengan alasan soal yang dibuat akan dikerjakan oleh kelompok lain, dapat berbagi pengetahuan dengan teman, menghilangkan sikap egois diri, lebih dekat dengan mahasiswa lain dan merasa terbantu dengan diskusi untuk memahami konsep asam basa.

\section{KESIMPULAN}

Berdasarkan uraian dan pembahasan sebelumnya, dapat disimpulkan hal-hal sebagai berikut: (a) Konsepsi awal mahasiswa ratarata sebesar $38,1 \%$ yang sesuai dengan para ahli pada konsep asam basa. (b) Konsepsi akhir mahasiswa setelah diajarkan dengan model problem posing bersetting kooperatif tipe think pair share rata-rata sebesar 91\% yang sesuai dengan para ahli. (c) Terdapat perbedaan yang signifikan antara kemampuan awal mahasiswa sebelum pembelajaran model problem posing bersetting think pair share dengan kemampuan akir mahasiswa setelah pembelajaran model problem posing bersetting tink pair share pada materi asam basa. (d) Besar pengaruh penggunaan model pembelajaran problem posing bersetting kooperatif tipe tinkh pair share terhadap kemampuan memahami konsep sangat tinngi dengan harga efek size 7,49. (e) Secara keseluruhan mahasiswa memberikan respon positif terhadap model pembelajaran problem posing bersetting tink pair share.

\section{E. SARAN}

Penelitian dengan menggunakan model problem posing bersetting kooperatif tipe think pair 
share memerlukan waktu yang cukup banyak. Namun, untuk mengatasi masalah tersebut dapat dilakukan strategi agar pembelajaran yang dilakukan tidak memakan waktu yang lama. Salah satunya dengan cara persentase dilakukan dengan kelompok pembuat soal untuk langsung dikoreksi tanpa memberikan komentar.

\section{DAFTAR PUSTAKA}

Akira Nakano, Tsukasa Hirashima, and Akira Takeuchi. 2002. A Learning Environment for Problem posing in Simple Arithmetical Word Problem. Japan : Kyushu Institute of Technology Department of Artificial Intelligence.

Ibrahim, M dkk. (2000). Pembelajaran Kooperatif. Surabaya: University Press.

Lie, A. 2004. Cooperatif Learning "Mempraktikkan

Cooperatif Learning di Ruang-Ruang Kelas. Jakarta: PT. Gramedia Widiasarana.

Mayer, R. E. 1999. Designing instruction for constructivist learning: Instructional design theories and models: $A$ new paradigm of instructional theory, volume II. New Jersey: Lawrence Erlbaum Associates, Publisher.

Suparno, Paul, 2004, Guru Demokratis di Era Reformasi, Grasindo, Jakarta. Pitalis ,M., Chistou, C. Mousoulides, N. and Pitta-Pantazi. 2004. $\boldsymbol{A}$ Structural Model For Problem Posing
Proceedings of the 28th Conference of the International Group for the Psychology of Mathematics Education, 2004 Vol 4 pp 4956.

Suryanto, 1998. Problem Posing dalam pembelajaran Matematika. Makalah pada seminar nasional:Program Pascasarjana IKIP Malang 4 April 1998. 
